\title{
Sekapur Sirih
}

\section{SAAT CYBERSEX TERPAPAR}

$\mathrm{K}$ ita percaya bahwa dalam keadaan normal orang-orang yang sudah dewasa dapat melakukan seleksi atas stimulus-stimulus yang berasal dari lingkungannya. Seberapapun kuat suatu stimulus, orang yang sudah dewasa tetap mampu bilang tidak atas stimulus yang mengenainya. Namun, mereka juga dapat berkata ya kalau mereka memilih untuk menyambutnya atau menerimanya. Itu keyakinan para ahli kognitif.

Dalam konteks cybersex, sumber informasi tentang seks yang luar biasa memesona itu bisa saja diabaikan oleh individu yang setiap saat bisa dengan sangat mudah mengaksesnya via internet. Ketika individu bilang tidak kepada cybersex, maka segenap informasi seputar seks itu tak akan memiliki kemampuan untuk memengaruhinya.

Namun, pertanyaannya: apakah kedewasaan itu merupakan sesuatu yang statis/mekanis? Para ahli psikologi umumnya percaya bahwa manusia senantiasa dalam interaksi yang aktif dengan dirinya sendiri dan lingkungannya. Di samping dapat memberikan pengaruh kepada lingkungannya, manusia dapat dipengaruhi individu lain dan hal-hal lain yang ada di luar dirinya. Stimulus yang begitu menarik memiliki kemampuan membetot perhatian sehingga manusia seakan tersihir untuk menerimanya dan menjadikan stimulus sebagai idolanya. Dorongan, pikiran, perasaan, dan perilaku manusia memiliki dinamika yang luar biasa. Sesuatu yang sebelumnya mampu ditepisnya bisa berubah menjadi sesuatu yang sangat disenanginya. Dorongan dari dalam yang senantiasa ingin dipuaskan (agama menyebutnya hawa nafsu) bisa mengubah pikiran, perasaan, dan perilakunya. Dorongan-dorongan yang kuat ini memang menjadi agenda setiap saat bagi manusia untuk dapat dikendalikan. Kita masih ingat ada seorang anggota DPR yang tidak kuat menahan dorongan dalam dirinya sehingga ketika berada di ruang sidang DPR ia malah sangat asyik mengakses situs-situs porno.

Tali kekang yang kita percayai memiliki kemampuan mengendalikan manusia adalah karakternya. Karakter adalah nilai-nilai utama yang memiliki kekuatan yang relatif stabil dalam diri individu yang dapat mengatur dorongan, pikiran, perasaan hingga perilaku individu. Ia terbentuk melalui pola asuh dan penguatan dari luar maupun dalam dirinya, sehingga ketika diekspresikan ke luar diri akan menjadi penanda siapa diri orang tersebut. Kebiasaan dan keteladanan dipercaya menjadi unsur utama pembentuk karakter manusia.

Dalam konteks cybersex, manusia yang memiliki karakter yang kuat akan memiliki pola perilaku yang memudahkan diri untuk menolak stimulasi seks yang begitu kaya itu. Dalam dirinya tersimpan apa yang disebut sebagai kejijikan moral (moral disgust). Saat berhadapan dengan stimulus yang melanggar etika kesucian, mereka menunjukkan emosi kejijikan. Hasil penelitian Agus Abdul Rahman dan Rendi Permadi (2013) yang dimuat dalam Psikologika edisi kali ini menunjukkan bahwa kejijikan moral memiliki pengaruh terhadap perilaku cybersex.

Perilaku yang dibiasakan adalah pembentuk utama karakter. Pertanyaan lanjutan yang dapat diajukan adalah apakah anak-anak (mulai bayi, kanak-kanak hingga usia sekolah) telah terbentuk karakternya sehingga mereka mampu menepis stimulasi cybersex yang terpaparke hadapan mereka?

Para ahli behaviorisme mengingatkan kita bahwa anak-anak adalah individu yang berada dalam fase pembentukan. Mereka sangat mudah tergoda dengan berbagai stimulasi yang ditawarkan dunia ini. Kenyataannya, ketika anak-anak sekolah disuruh gurunya untuk mengakses internet demi menjawab tugas-tugas sekolah, ternyata mayoritas mereka mampir dulu ke situs-situs seks.

Karena ketergantungan yang masih 
besar terhadap stimulasi eksternal ini, maka pihak-pihak yang berwenang mestinya membantu anak-anak agar tidak terganggu oleh berbagai stimulasi cybersex. Pemerintah memegang peranan paling penting untuk membantu anak-anak terjauh dari paparan stimulasi cybersex. Pemerintah negara-negara maju yang komitnya tinggi dalam melindungi rakyatnya bisa membuat regulasi yang memungkinkan stimulasi perusak itu diminimalisasi. Pemerintah negara kita pun mestinya berjuang optimal untuk menjauhkan anak-anak dari stimulasi yang menjijikkan secara moral.
Upaya untuk meminimalisasi stimulasi eksternal ini mestinya juga dibarengi oleh penguatan karakter individu. Usaha untuk membantu individu memiliki karakter kejijikan moral sehingga mereka memiliki kepekaan untuk . Orangtua dan guru berada di garda depan untuk membantu anak-anak memiliki moral disgust ini.,

Demikian. Wallahu a'lam bi ashshawab.

Email: fuadnashori@yahoo.com 